\title{
Depth Wise Distribution of Heavy Metals in Different Soil Series of Northwestern India
}

\author{
Ganpat Louhar $^{1 *}$, Rajpaul Yadav ${ }^{1}$, R.S. Malik ${ }^{1}$ and Suresh Yadav ${ }^{2}$ \\ ${ }^{1}$ Department of Soil Science, CCS Haryana Agricultural University Hisar - 125004, India \\ ${ }^{2}$ Division of Genetics, Indian Agricultural Research Institute, New Delhi, 110012, India \\ *Corresponding author
}

\section{Keywords}

Depth wise

distribution, Field

survey, Heavy

metals, Soil series

Article Info

Accepted:

20 January 2019

Available Online:

10 February 2019

\section{A B S T R A C T}

A field survey and laboratory analysis carried out on "Depth wise Distribution of Heavy Metals in Different Soil Series of Northwestern India" was conducted during 2017-18 in five well established soil series which are comes under Aeolian and upper alluvial plain of Hisar district. The profile samples up to depth of $90 \mathrm{~cm}$. i.e. 0-15, 15-30, 30-60, 60-90 cm, using GPS were collected and analyzed for total concentrations of heavy metals $(\mathrm{Pb}, \mathrm{Cr}$, $\mathrm{Cd}$, Co and Ni). The total lead content was initially increased with depth then further decreased in Balsamand. In Isarwal and Rawalwas it was increased with depth but in Barwala decreased with depth. In Ladwa soil series first increased then decreased. The total chromium content of Balsamand first increased with depth then decreased. In Isarwal and Rawalwas it was decreased with depth. In Barwala and Ladwa series initially decreased then further increased. The total cadmium of Balsamand and Isarwal first increased with depth then decreased. In Isarwal increased and decreased in Barwala. In Ladwa series initially decreased then further increased. The total cobalt was increased with depth in Balsamand, Isarwal and Rawalwas series. In Barwala decreased with depth and in Ladwa increased first then decreased. The total nickel content was increased with depth in Balsamand, Isarwal and Rawalwas series. In Barwala decreased with depth and in Ladwa first increased then further decreased. The non uniform distribution of total heavy metals contents were found in all series.

\section{Introduction}

Soil serves as a sink for some noxious elements known as heavy metals i.e. lead, chromium, cadmium, cobalt and nickel where they persist in soil for long period of times, caused detrimental effects on health and quality of agricultural soils and crops (Nicholsona et al., 2003). Due to anthropogenic activities, they add harmful and toxic metals in soil which indirectly affects on human's health through food chain (Simeonov et al., 2003). The upper $25 \mathrm{~cm}$ surface layer of soil is mostly affected by the toxic metals where the roots of the plants or crops located (Freitas et al., 2004). The anthropogenic activities which contribute pollution to water bodies are industrial and 
sewage effluents, domestic sewage, surface washing, organic matter of plants and animals, agrochemicals and treatment work's wastes (Lokeshwari and Chandrappa, 2006). Soils are the major sinks for heavy metals released into the environment by above mentioned anthropogenic activities and unlike organic contaminants which are oxidized to carbon (IV) oxide by microbial action, most metals do not undergo microbial or chemical degradation and their total concentration in soils persists for a long period of time after their introduction. Heavy metals are mainly originated from basic igneous rocks, in which the levels of metals are higher compared as compared to other rocks such as granites, gneisses, sandstones and siltstones (Tiller, 1989; Fadigas et al., 2006). Other factors such as proportion and composition of the clay and organic matter may also influence the levels of heavy metals in soils (Barona and Romero, 1996). Heavy metals are very harmful due to their non biodegradable nature. Soil organic matter that plays a key role in governing the metal mobility consists mainly of humic substances- humic and fulvic acids. The heavy metals in soil cannot be destroyed like organic contaminants, but only be relocated from one place (contaminated site) to another place, e.g. landfill, which is, however, a very expensive procedure. Therefore, alternative strategies were developed to reduce risks and contamination which are associated with heavy metals in soils and to minimize potential impacts on plants, animals, water quality and consequently on human health. The increase of contaminants in soil can be hindered by soil stabilization techniques, which is based on an application of suitable immobilizing agents. Adsorption of contaminants on mineral surfaces, formation of stable complexes with organic ligands, surface precipitation and ion-exchange were identified as the main mechanisms responsible for the reduction of the metal mobility, leachability and bioavailability. No such work i.e. depth wise distribution of heavy metals, has been carried out in soil series of Hisar district (Haryana). Thus, keeping in view the above facts, the present study was carried out.

\section{Materials and Methods}

\section{Location and study area}

The present study of depth wise distribution of heavy metals in different soil series of Hisar district of Hisar division in the state of Haryana in northwestern India (Table 1). This study was conducted in a part of the IndoGangetic alluvial plain, which lies between $28.59^{\prime}$ to $29.49^{\prime} \mathrm{N}$ latitude and $75.11^{\prime}$ to $76.18^{\prime}$ longitude. For the analysis of total content of $\mathrm{Pb}, \mathrm{Cr}, \mathrm{Cd}, \mathrm{Co}$ and $\mathrm{Ni}$, soil samples were collected up to depth of $90 \mathrm{~cm}$. i.e. 0-15, $15-30,30-60,60-90 \mathrm{~cm}$, with the help of GPS system (Global Positioning System) from the five well established soil series of Hisar district, which are comes under Aeolian and upper Alluvial Plain of Hisar district (Fig. 1).

\section{Experimental details}

Total content of heavy metals $(\mathrm{Pb}, \mathrm{Cr}, \mathrm{Cd}, \mathrm{Co}$ and $\mathrm{Ni}$ ) was analyzed by following Procedure:

- Transfer $0.1 \mathrm{~g}$ of soil in a $50 \mathrm{ml}$ beaker and add $20 \mathrm{ml}$ diacid mixture of $\mathrm{HNO}_{3}$ and $\mathrm{HClO}_{4}$ (4:1 ratio).

- Keep it for two days overnight.

- Keep on a hot plate and heat gently at first.

- Then heat more until a clear colorless solution or till while fumes cease to come out.

- Don't take it to dryness.

- Discontinue heating, when the volume is reduced to 1-2 ml. 
- Cool it and adding $25 \mathrm{ml}$ distilled water then filter through Whatman No. 42 filter paper.

- Determine the contents of total heavy metals $(\mathrm{Pb}, \mathrm{Cr}, \mathrm{Cd}, \mathrm{Co}$ and $\mathrm{Ni})$ by Atomic Absorption Spectrophotometer using respective cathode lamps.

- A blank solution (without soil) should also be run.

\section{Results and Discussion}

\section{Total Lead $(\mathrm{Pb})$}

The total lead of profile soil samples from 0 $15,15-30,30-60$ and $60-90 \mathrm{~cm}$ of Balsamand soil series was $10.00,57.50,35.00$ and 47.50 $\left(\mathrm{mg} \mathrm{kg}^{-1}\right)$, respectively (Table 2), Isarwal soil series from 50.00, 55.00, 62.50 and 72.50, respectively and in Rawalwas soil series the $\mathrm{Pb}$ content was 47.50, 60.00, 62.50 and 80.00 $\left(\mathrm{mg} \mathrm{kg}^{-1}\right)$, respectively. However in Barwala soil series the total heavy metal content was 105.00, 32.50, 27.50 and 40.00, respectively and in Ladwa soil series 27.50, 107.50, 110.00 and 37.50 , respectively. The total lead $\left(\mathrm{mg} \mathrm{kg}^{-1}\right)$ of study area was ranged from in 0 $15 \mathrm{~cm}$. depth minimum (10.00) in Balsamand and maximum (105.00) in Barwala; $15-30 \mathrm{~cm}$ minimum (32.50) in Barwala and maximum (107.50) Ladwa; 30-60 cm minimum (27.50) in Barwala and maximum (110.00) in; 60$90 \mathrm{~cm}$ minimum (40.00) in Barwala and maximum (80.00) in Rawalwas soil series. While studied the distribution of heavy metals in French soils from nonpolluted areas, Hernandeza et al., (2003) also found similar results which are associated with present study. The average abundance order of heavy metal contents were: $\mathrm{Cr}>\mathrm{Zn}>\mathrm{Pb}>\mathrm{Ni}>$ $\mathrm{Cu}>\mathrm{Co}>\mathrm{Cd}$. The calcariccambisol enriched with all heavy metals, except $\mathrm{Cd}$. The distribution of heavy metal with depth varies according to the element and soil type. Sandy acid rocks having very low metal content, except $\mathrm{Pb}$ and basalts and calcareous contain
$\mathrm{Ni}$ and $\mathrm{Cr}$ (Fig. 2-6). The concentration of $\mathrm{Cr}$ and $\mathrm{Co}$ increases in most soils with depth, except the ferric podzol and the dystric planosol for which Co decreases and the lowest Co concentrations are in acidic soils. $\mathrm{Ni}$ concentration increases with depth in almost all soils samples, except for the ferric podzol in which the intermediate horizons are enriched. Cd content decreases with depth or it remains stable, with the exception of the stagnicluvisol where it increases and the ferric podzol where it accumulates in the Eh horizon like $\mathrm{Cu}$ and $\mathrm{Zn}$. The highest $\mathrm{Pb}$ concentrations in surface horizons and $\mathrm{Pb}$ content decreases with depth. The clay content increases significantly with depth, however for $\mathrm{Pb}$; the enrichment found in the deep rich clay horizon of the dystric planosol is very low.

\section{Total Chromium (Cr)}

The data on total chromium content $\left(\mathrm{mg} \mathrm{kg}^{-1}\right)$ of Balsamand soil series in different depths was $10.50,30.25,20.25$ and 17.50, respectively, Isarwal soil series was 82.75 , $2.75,8.75$ and 21.00 , respectively (Table 3 ), Rawalwas 50.75, 6.75, 11.25 and 20.75, respectively, Barwala soil series 47.25, 17.00, 30.50 and 92.25 , respectively and in Ladwa soil series 54.00, 30.50, 27.00 and 50.25, respectively. The total chromium $\left(\mathrm{mg} \mathrm{kg}^{-1}\right)$ of study area in $0-15 \mathrm{~cm}$. depth, minimum (10.50) in Balsamand and maximum (82.75) in Isarwal; $15-30 \mathrm{~cm}$ minimum (2.75) Isarwal and maximum (30.50) Ladwa; 30-60 cm minimum (8.75) in Isarwal and maximum (30.50) in Barwala; $60-90 \mathrm{~cm}$ minimum (21.00) in Isarwal and maximum (92.25) in Barwala soil series. While studied the total chromium content of 'vertisols and verticinceptisols' of Ethiopia, Yerima et al., (2013) also found similar results. Decreased in depth is associated with decreases in organic carbon contents and increasing $\mathrm{pH}$ that causes reduced metal solubility. This is reliable with findings by Sharma et al., (2006) 
for Indian soil. Cobalt concentrations were generally decreased with depth. Lead has not shown a definite pattern in surface horizons but generally increased with depth in the lower sola. Cadmium concentrations in all the horizons were $<0.02 \mathrm{ug} \mathrm{g}^{-1}$. Trace amounts of cadmium and decreasing concentrations of cobalt with depth may be attributable to the increasing $\mathrm{pH}$ and $\mathrm{CaCO}_{3}$ content which has been experimental to reduce the solubility of heavy metals (McBride, 1979). Generally, the decreasing heavy metal content trend with depth can be attributed to the recycling of essential nutrients to the surface horizons by plants. Organic matter content was concentrated in the surface A-horizons by the process of melanization (Lee et al., 1997). As organic matter (roots and other plant and animal tissue) decompose, plant-essential soluble heavy metals are released into the soil to the surface ' $\mathrm{A}$ ' horizon and subsequently adsorbed on clay minerals. Generally, there is a decrease in DTPA-extractable heavy metals with depth (except $\mathrm{Pb}$ and $\mathrm{Cd}$ ). However, the high and near uniform distribution of these elements (except $\mathrm{Cd}$ ) in the B horizons is associated with sorption and pedoturbation resulting from the high clay contents (clay contents exceed $70 \%$ in most of the B horizons) with shrink-swell properties. Lead and $\mathrm{Cd}$ are not concentrated by melanization in the organic matter-rich ' $A$ ' horizons of these soils.

Table.1 Location of study area

\begin{tabular}{|c|l|c|c|}
\hline S. No. & Name of Series & Latitude (N) & Longitude (E) \\
\hline $\mathbf{1 .}$ & Balsamand & $29^{\circ} 05^{\prime} 293^{\prime}$ & $75^{\circ} 44^{\prime} 560^{\prime \prime}$ \\
\hline $\mathbf{2 .}$ & Isarwal & $29^{\circ} 06^{\prime} 393^{\prime}$ & $75^{\circ} 46^{\prime} 436^{\prime}$ \\
\hline $\mathbf{3 .}$ & Rawalwas & $29^{\circ} 08^{\prime} 716^{\prime \prime}$ & $75^{\circ} 58^{\prime} 162^{\prime \prime}$ \\
\hline $\mathbf{4 .}$ & Barwala & $29^{\circ} 23^{\prime} 389^{\prime}$ & $75^{\circ} 90^{\prime} 884^{\prime \prime}$ \\
\hline $\mathbf{5 .}$ & Ladwa & $29^{\circ} 15^{\prime} 036^{\prime}$ & $75^{\circ} 90^{\prime} 884^{\prime \prime}$ \\
\hline
\end{tabular}

Table.2 Total lead content $\left(\mathrm{mg} \mathrm{kg}^{-1}\right)$ in profile samples of different soil series of Hisar

\begin{tabular}{|l|c|c|c|c|}
\hline \multirow{2}{*}{ Soil series } & \multicolumn{4}{|c|}{ Depth (cm) } \\
\cline { 2 - 5 } & $\mathbf{0 - 1 5}$ & $\mathbf{1 5 - 3 0}$ & $\mathbf{3 0 - 6 0}$ & $\mathbf{6 0 - 9 0}$ \\
\hline Balsamand & 10.00 & 57.50 & 35.00 & 47.50 \\
\hline Isarwal & 50.00 & 55.00 & 62.50 & 72.50 \\
\hline Rawalwas & 47.50 & 60.00 & 62.50 & 80.00 \\
\hline Barwala & 105.00 & 32.50 & 27.50 & 40.00 \\
\hline Ladwa & 27.50 & 107.50 & 110.00 & 37.50 \\
\hline
\end{tabular}

Table.3 Total chromium content $\left(\mathrm{mg} \mathrm{kg}^{-1}\right)$ in profile samples of different soil series of Hisar

\begin{tabular}{|l|c|c|c|c|}
\hline \multirow{2}{*}{ Soil series } & \multicolumn{4}{|c|}{ Depth (cm) } \\
\cline { 2 - 5 } & $\mathbf{0 - 1 5}$ & $\mathbf{1 5 - 3 0}$ & $\mathbf{3 0 - 6 0}$ & $\mathbf{6 0 - 9 0}$ \\
\hline Balsamand & 10.50 & 30.25 & 20.25 & 17.50 \\
\hline Isarwal & 82.75 & 2.75 & 8.75 & 21.00 \\
\hline Rawalwas & 50.75 & 6.75 & 11.25 & 20.75 \\
\hline Barwala & 47.25 & 17.00 & 30.50 & 92.25 \\
\hline Ladwa & 54.00 & 30.50 & 27.00 & 50.25 \\
\hline
\end{tabular}


Table.4 Total cadmium content $\left(\mathrm{mg} \mathrm{kg}^{-1}\right)$ in profile samples of different soil series of Hisar

\begin{tabular}{|l|c|c|c|c|}
\hline \multirow{2}{*}{ Soil series } & \multicolumn{4}{|c|}{ Depth (cm) } \\
\cline { 2 - 5 } & $\mathbf{0 - 1 5}$ & $\mathbf{1 5 - 3 0}$ & $\mathbf{3 0 - 6 0}$ & $\mathbf{6 0 - 9 0}$ \\
\hline Balsamand & 1.00 & 1.50 & 0.25 & 0.50 \\
\hline Isarwal & 1.50 & 1.75 & 1.75 & 2.25 \\
\hline Rawalwas & 2.00 & 3.50 & 4.25 & 2.50 \\
\hline Barwala & 2.25 & 1.00 & 1.50 & 1.25 \\
\hline Ladwa & 1.75 & 0.75 & 2.25 & 3.25 \\
\hline
\end{tabular}

Table.5 Total cobalt content $\left(\mathrm{mg} \mathrm{kg}^{-1}\right)$ in profile samples of different soil series of Hisar

\begin{tabular}{|l|c|c|c|c|}
\hline \multirow{2}{*}{ Soil series } & \multicolumn{4}{|c|}{ Depth $(\mathbf{c m})$} \\
\cline { 2 - 5 } & $\mathbf{0 - 1 5}$ & $\mathbf{1 5 - 3 0}$ & $\mathbf{3 0 - 6 0}$ & $\mathbf{6 0 - 9 0}$ \\
\hline Balsamand & 0.00 & 0.67 & 0.37 & 0.67 \\
\hline Isarwal & 0.00 & 0.00 & 0.85 & 0.92 \\
\hline Bawalwas & 0.00 & 0.15 & 0.87 & 1.05 \\
\hline Ladwa & 2.35 & 0.52 & 0.00 & 0.00 \\
\hline
\end{tabular}

Table.6 Total nickel content $\left(\mathrm{mg} \mathrm{kg}^{-1}\right)$ in profile samples of different soil series of Hisar

\begin{tabular}{|l|c|c|c|c|}
\hline \multirow{2}{*}{ Soil series } & \multicolumn{4}{|c|}{ Depth (cm) } \\
\cline { 2 - 5 } & $\mathbf{0 - 1 5}$ & $\mathbf{1 5 - 3 0}$ & $\mathbf{3 0 - 6 0}$ & $\mathbf{6 0 - 9 0}$ \\
\hline Balsamand & 2.50 & 12.50 & 22.50 & 23.00 \\
\hline Isarwal & 8.00 & 9.00 & 10.25 & 12.75 \\
\hline Bawalwas & 5.00 & 7.50 & 11.25 & 19.75 \\
\hline Ladwa & 45.50 & 26.00 & 22.50 & 11.25 \\
\hline
\end{tabular}

Fig.1 Map of Haryana showing Hisar district; Source: www.mapsofindia.com

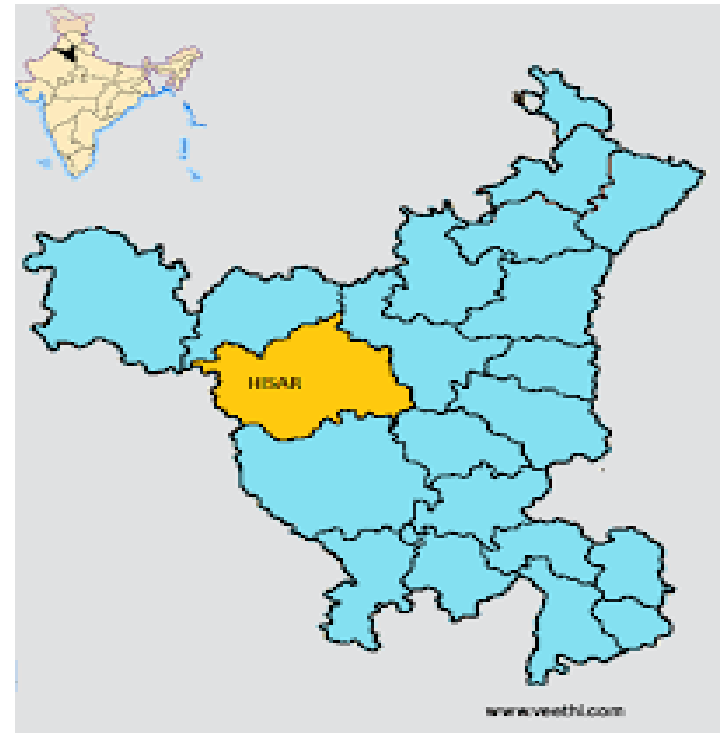


Fig.2 Distribution of different heavy metals in Balsamand soil series

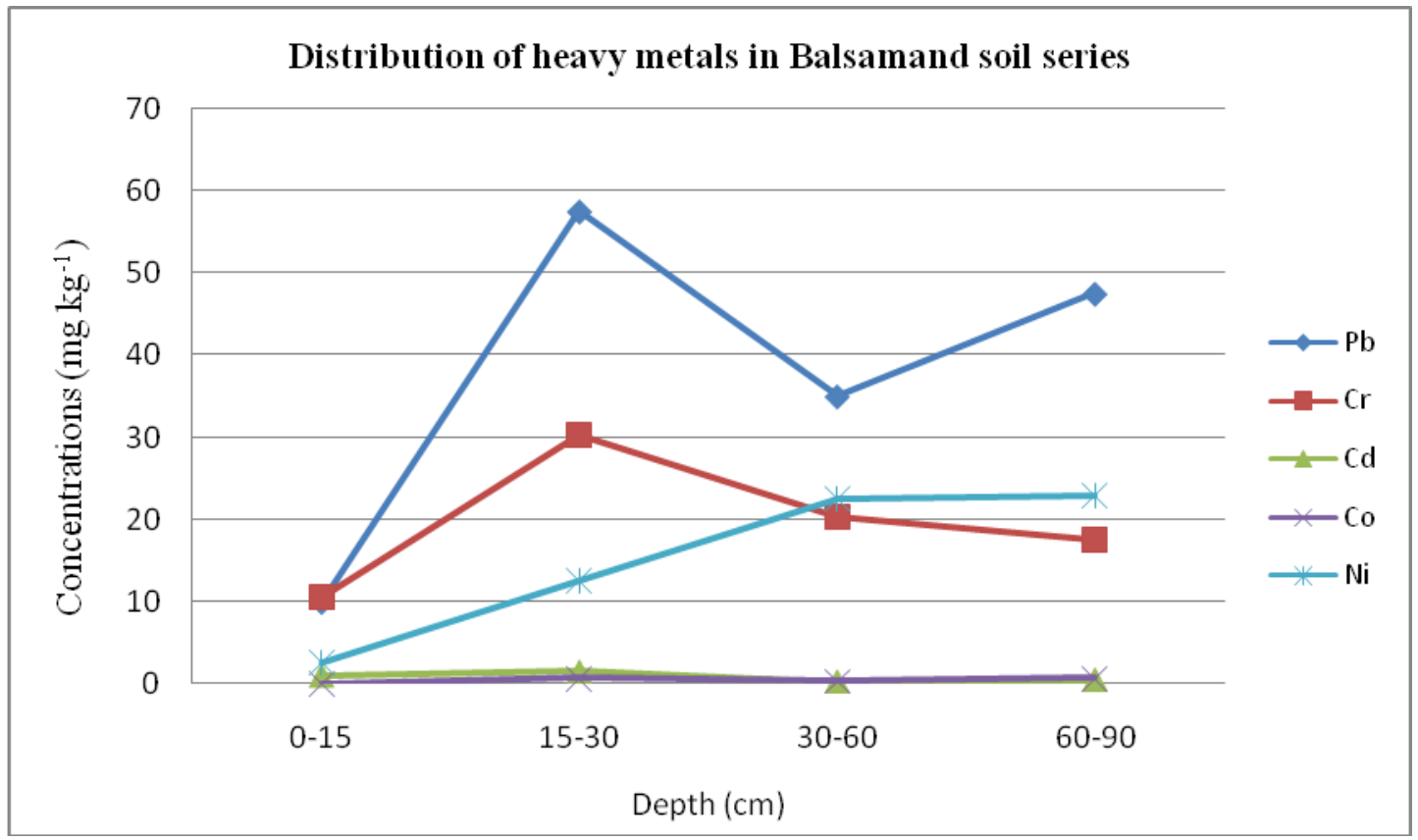

Fig.3 Distribution of different heavy metals in Isarwal soil series

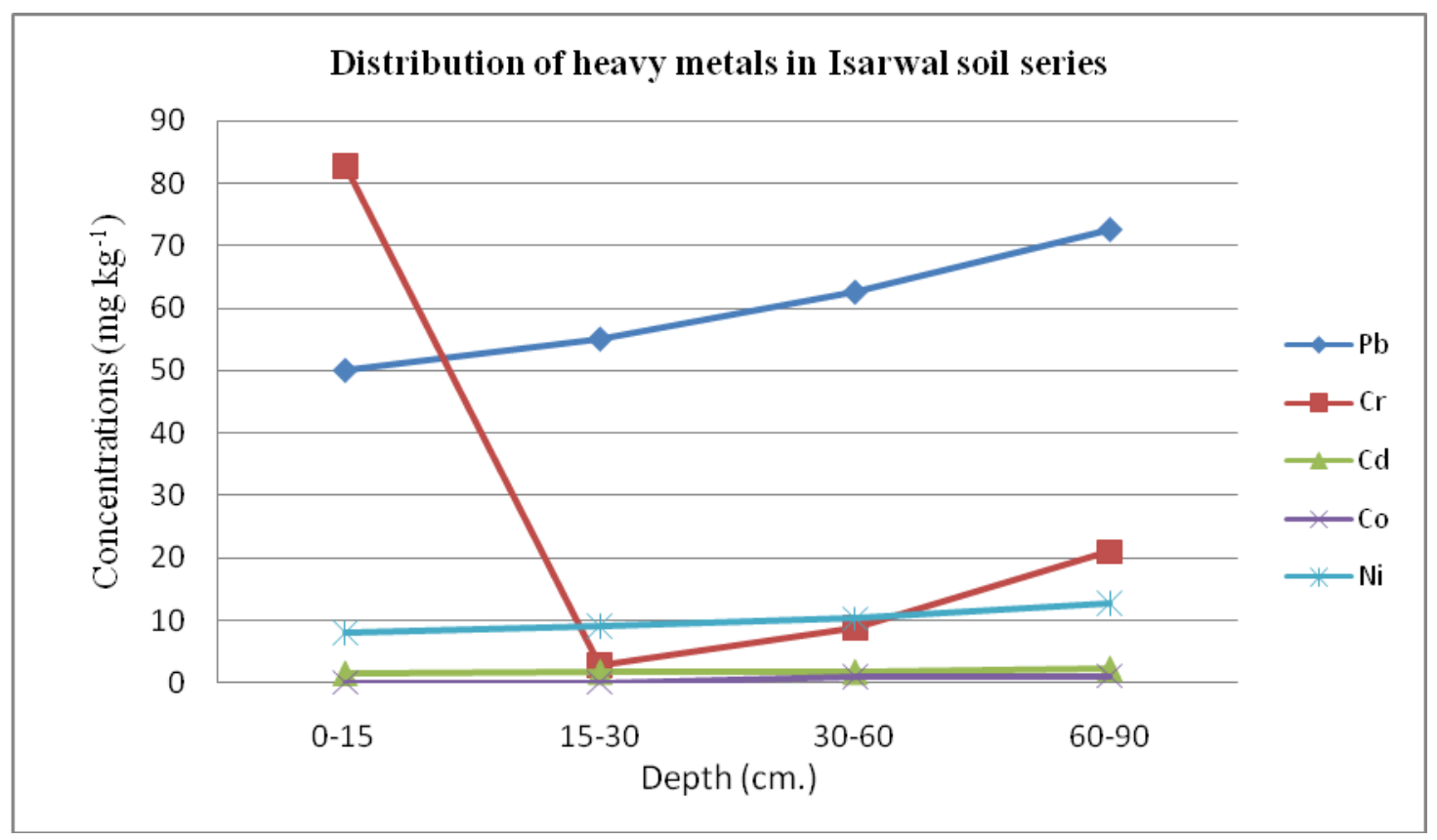


Fig.4 Distribution of different heavy metals in Rawalwas soil series

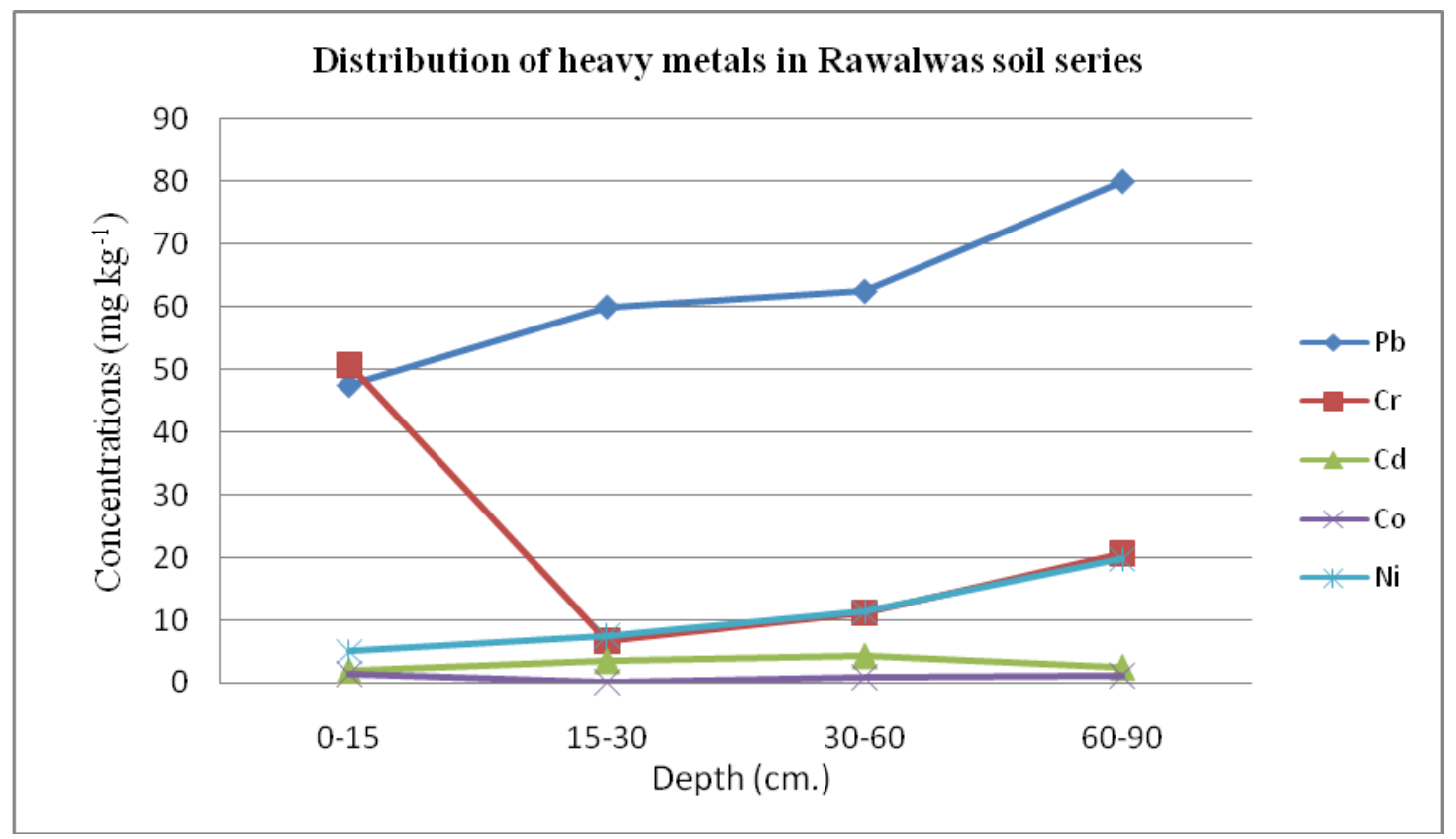

Fig.5 Distribution of different heavy metals in Barwala soil series

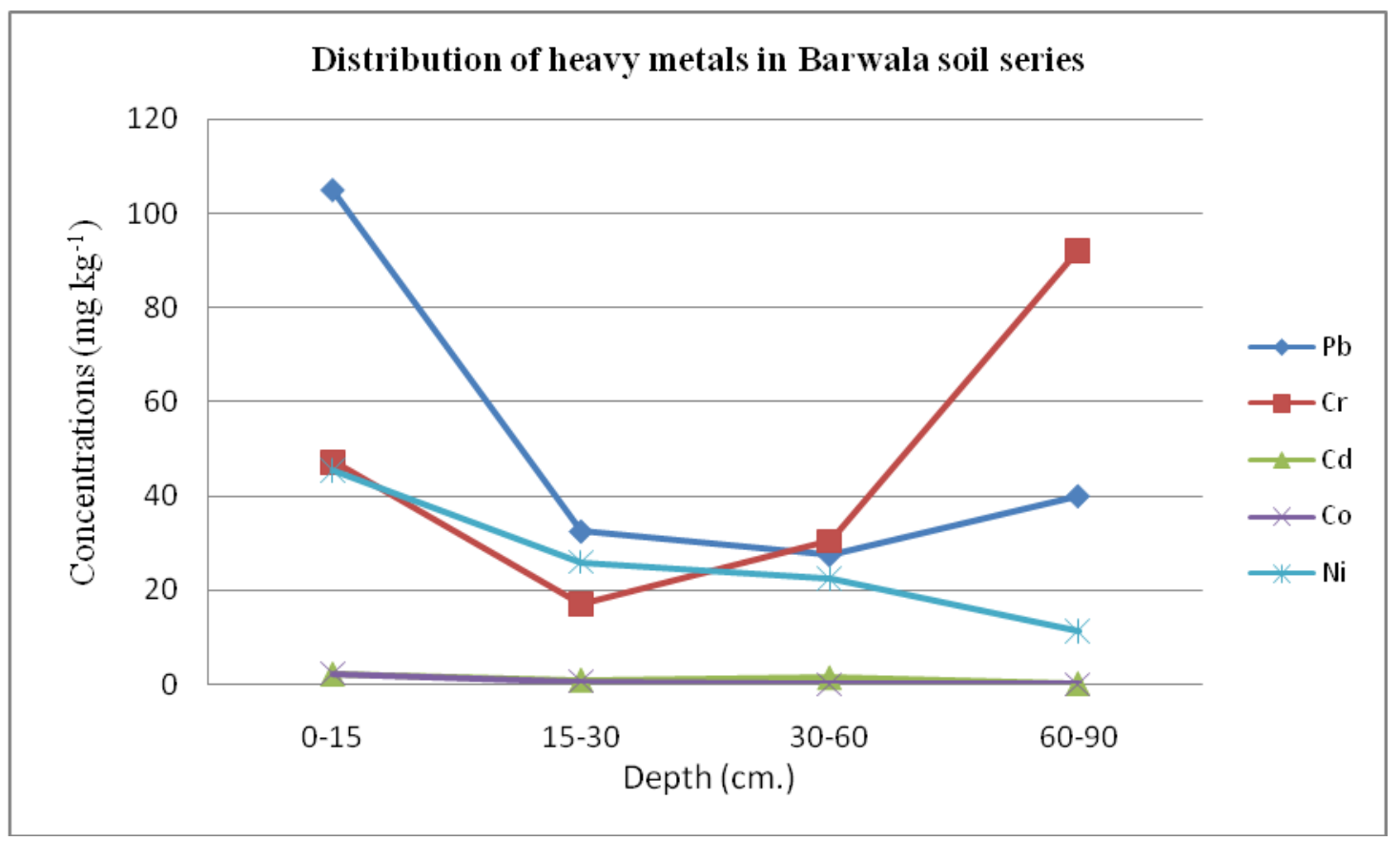


Fig.6 Distribution of different heavy metals in Ladwa soil series

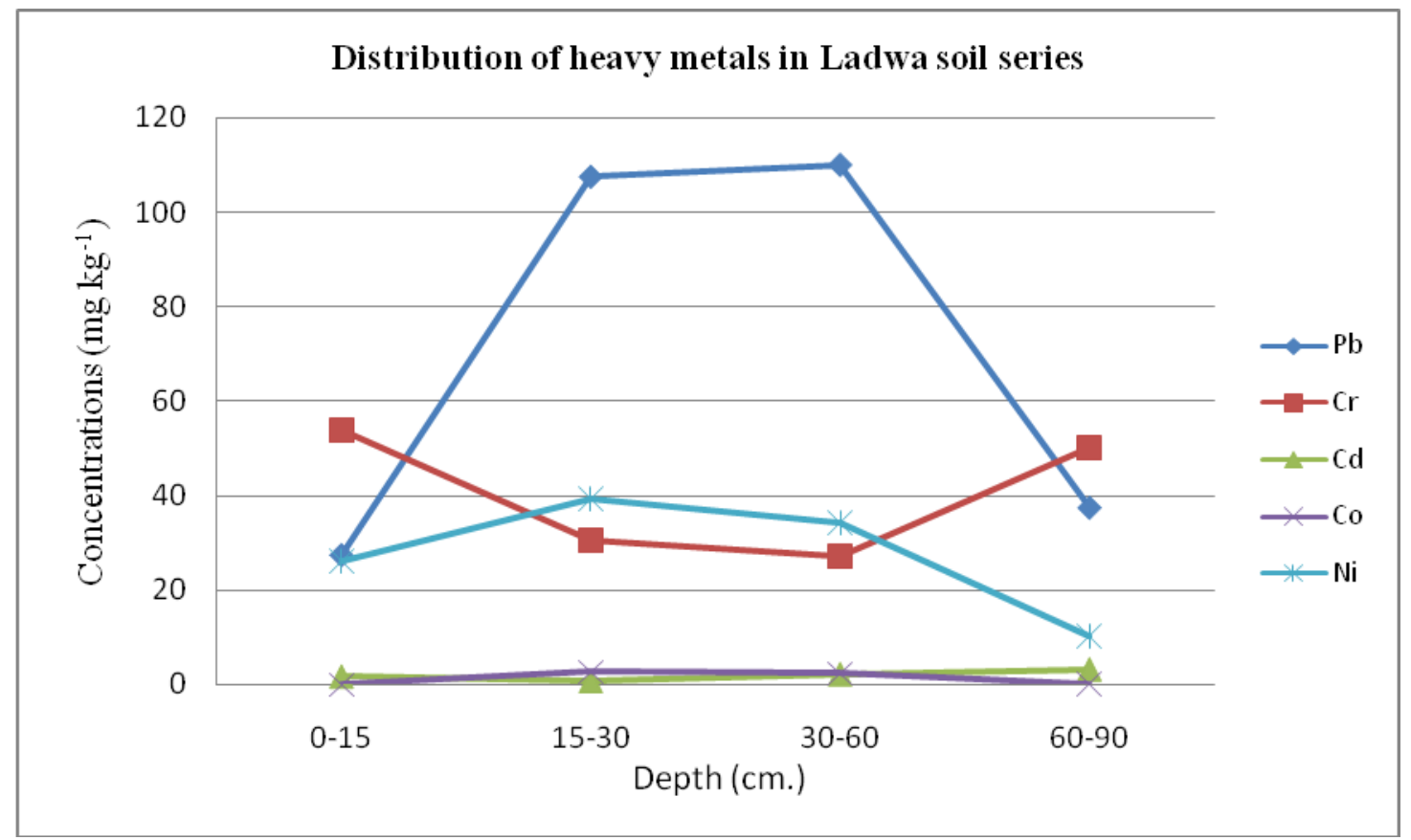

\section{Total Cadmium $(\mathbf{C d})$}

The total cadmium $\left(\mathrm{mg} \mathrm{kg}^{-1}\right)$ content of Balsamand soil series $1.00,1.50,0.25$ and 0.50 , respectively, Isarwal soil series 1.50 , $1.75,1.75$ and 2.25 , respectively, Rawalwas series $2.00,3.50,4.25$ and 2.50 , respectively (Table 4), Barwala 2.25, 1.00, 1.50 and 1.25, respectively and Ladwa soil series $1.75,0.75$, 2.25 and $3.25\left(\mathrm{mg} \mathrm{kg}^{-1}\right)$, respectively. The total cadmium $\left(\mathrm{mg} \mathrm{kg}^{-1}\right)$ was ranged from $0-15 \mathrm{~cm}$. depth minimum (1.00) in Balsamand and maximum (2.25) in Barwala; $15-30 \mathrm{~cm}$ minimum (0.75) in Ladwa and maximum (3.50) in Rawalwas; $30-60 \mathrm{~cm}$ minimum $(0.25)$ in Balsamand and maximum (4.25) in Rawalwas; $60-90 \mathrm{~cm}$ minimum (0.25) in Barwala and maximum (3.25) in Ladwa soil series. While studied total cadmium of profiles samples of Dongguan City (China Guo et al., (2013) also found similar results which are related to present study. They found that $\mathrm{Cu}, \mathrm{Zn}, \mathrm{Pb}, \mathrm{Cd}$, and $\mathrm{Hg}$ concentrations in top soils were higher than those in the subsoil of vegetable fields. In banana fields, only $\mathrm{Pb}$ and $\mathrm{Hg}$ concentrations in topsoil were obviously higher than those in subsoils. Cd has accumulated only in topsoil of vegetable fields, but $\mathrm{Pb}$ and $\mathrm{Hg}$ accumulated in top soils of both banana and vegetable fields. The $\mathrm{Pb}$ concentration was higher in the vegetable field than in the banana field.

\section{Total Cobalt (Co)}

The data on total cobalt $\left(\mathrm{mg} \mathrm{kg}^{-1}\right)$ of Balsamand soil series $0.00,0.67,0.37$ and 0.67 , respectively, Isarwal soil series 0.00 , $0.00,0.85$ and 0.92 , respectively Rawal was soil series $0.00,0.15,0.87$ and 1.05, respectively, Barwala soil series $2.35,0.52$, 0.00 and 0.00 , respectively (Table 5) and Ladwa soil series $0.00,2.65,2.47$ and 0.07 , respectively. The total cobalt $\left(\mathrm{mg} \mathrm{kg}^{-1}\right)$ of study area was found in $0-15 \mathrm{~cm}$. depth ranged from minimum (00.00) in Balsamand, Isarwal, Ladwa soil series and maximum (2.35) in Ladwa soil series; $15-30 \mathrm{~cm}$ minimum (00.00) in Isarwal and maximum 
(2.65) Ladwa; $30-60 \mathrm{~cm}$ minimum (00.00) in Barwala and maximum (2.47) in Ladwa; 60$90 \mathrm{~cm}$ minimum (00.00) in Barwala and maximum (1.05) in Rawalwas soil series. While studying the distribution of heavy metals in French soils from non polluted areas, Hernandeza et al., (2003) also found similar results.

\section{Total Nickel (Ni)}

The total nickel content of Balsamand soil series in $2.50,12.50,22.50$ and $23.00(\mathrm{mg}$ $\mathrm{kg}^{-1}$ ), respectively, Isarwal series 8.00, 9.00, 10.25 and 12.75, respectively, Rawalwas 5.00, 7.50, 11.25 and 19.75, respectively, Barwala soil 45.50, 26.00, 22.50 and 11.25, respectively and in Ladwa soil series 26.00, $39.25,34.25$ and 10.25, respectively, (Table $6)$. The total nickel $\left(\mathrm{mg} \mathrm{kg}^{-1}\right)$ was found in 0 $15 \mathrm{~cm}$. depth ranged from minimum (5.00) in Rawalwas and maximum (45.50) in Barwala; $15-30 \mathrm{~cm}$ minimum (7.50) in Rawalwas and maximum (39.25) Ladwa; 30-60 cm minimum (10.25) in Isarwal and maximum (34.25) in Ladwa series; $60-90 \mathrm{~cm}$ minimum (10.25) in Ladwa and maximum (19.75) in Rawalwas soil series. While studied the total nickel content of 'vertisols and verticin ceptisols' of Ethiopia, Yerima et al., (2013) also found similar results which are associated with present study.

In conclusion, the present study showed that the total heavy metal content in profile soil samples of Hisar district was found below toxic limit (within the permissible limit). Their non uniform distribution of heavy metals $(\mathrm{Pb}, \mathrm{Cr}, \mathrm{Cd}, \mathrm{Co}$ and $\mathrm{Ni})$ was found in all above five well established soil series. Therefore, this type of study are very useful to reduce risks and heavy metal contamination in soils and to minimize potential impacts on plants, animals, water quality and consequently on human health.

\section{Acknowledgments}

The authors are extremely grateful to the Head, Department of Soil Science, Hisar, Haryana, India for his support and facilitation for carrying out the research work successfully.

\section{References}

Barona, A., and Romero, F. 1996. Distribution of metals in soils relationships among fractions by principal component analysis. Soil Technology, 8: 303-319.

Fadigas, F.S., Sobrinho, N.M.B.A., Anjos, L.H.C. D. and Mazur, N. 2006. Estimation of reference values for cadmium, cobalt, chromium, copper, nickel, lead, and zinc in Brazilian soils. Communications in Soil Science and Plant Analysis, 37: 945-959.

Freitas, H., Prasad, M.N. V. and Pratas, J. 2004. Plant community tolerant to trace elements growing on the degraded soils of Sao Domingos mine in the South East of Portugal. Environment International, 30 (1):65-72.

Guo, Y.B., Feng, H., Chen, C., Jia, C.J., Xiong, F. andLu, Y. (2013). Heavy metal concentrations in soil and agricultural products near an industrial district. Polish Journal of Environmental Studies, 22 (5): 13571362.

Hernandeza, L., Probsta, A., Probsta, J.L. and Ulrichb, E. 2003. Heavy metal distribution in some French forest soils: evidence for atmospheric contamination. Advances in Soil Science, 8: 115-130.

Lee, B.D., Carter, B.J., Basta, N. T. and Weaver, B. 1997. Factors influencing heavy metal distribution in six Oklahoma benchmark Soils. Soil Science Society of America Journal, 61: 
218-223.

Lokeshwari, H., and Chandrappa, G.T. 2006. Impact of heavy metal contamination of Bellandur Lake on soil and cultivated vegetation. Current Science, 91(5):623628.

McBride, M.B., 1979. Chemisorption and precipitation of $\mathrm{Mn}$ at $\mathrm{CaCO}_{3}$ surfaces. Soil Science Society of America Journal, 43: 693-698.

Nicholsona, F.A., Smith, S.R., Alloway, B.J., Smith, C. C. and Chambersa, B.J. 2003. An inventory of heavy metals inputs to agricultural soils in England and Wales. Science of the Total Environment, 311 (1-3):205-219.

Sharma, B.D., Mukhopadhyay, S.S. and Katyal, J.C. 2006. Distribution of total and DTPA-extractable zinc, copper, Manganese and iron in Vertisols of India. Communications in Soil Science and Plant Analysis, 5: 653-672.

Simeonov, V., Stratis, J.A., Samara, C., Zachariadis, G., Voutsa, D. Anthemidis, A., Sofoniou, M. and Kouimtzis, T. 2003. Assessment of the surface water quality in northern Greece. Water Research, 37(17): 4119 4124.

Tiller, K.G., 1989. Heavy metals in soil and their environmental significance. Advances in Soil Science, 9: 113-142.

Yerima, B.P.K., Ranst, E. V., Sertsu, S. andVerdood, A. 2013. Pedogenic impacts on the distribution of total and available $\mathrm{Fe}, \mathrm{Mn}, \mathrm{Cu}, \mathrm{Zn}, \mathrm{Cd}, \mathrm{Pb}$ and Co contents of vertisols and verticinceptisols of the Bale Mountain area of Ethiopia, African journal of agricultural research, 8 (44): 54295439.

\section{How to cite this article:}

Ganpat Louhar, Rajpaul Yadav, R.S. Malik and Suresh Yadav. 2019. Depth Wise Distribution of Heavy Metals in Different Soil Series of Northwestern India. Int.J.Curr.Microbiol.App.Sci. 8(02): 2817-2826. doi: https://doi.org/10.20546/ijcmas.2019.802.331 